\title{
Interaction of Adenine Adducts with Thymine: A Computational Study
}

\author{
Prabhat K. Sahu, Chang-Wang Kuo, and Shyi-Long Lee* \\ Department of Chemistry and Biochemistry, National Chung Cheng University, Chia-Yi, 621 Taiwan
}

Received: October 18, 2006; In Final Form: December 6, 2006

\begin{abstract}
The existence of DNA adducts bring the danger of carcinogenesis because of mispairing with normal DNA bases. 1,N6-ethenoadenine adducts $(\epsilon \mathrm{A})$ and $1, N^{6}$-ethanoadenine adducts (EA) have been considered as DNA adducts to study the interaction with thymine, as DNA base. Several different stable conformers for each type of adenine adduct with thymine, $[\epsilon \mathrm{A}(1)-\mathrm{T}(\mathrm{I}), \epsilon \mathrm{A}(2)-\mathrm{T}(\mathrm{I}), \epsilon \mathrm{A}(3)-\mathrm{T}(\mathrm{I})$ and $\mathrm{EA}(1)-\mathrm{T}(\mathrm{I}), \mathrm{EA}(2)-\mathrm{T}(\mathrm{I})$, $\mathrm{EA}(3)-\mathrm{T}(\mathrm{I})]$ and $[\epsilon \mathrm{A}(1)-\mathrm{T}(\mathrm{II}), \epsilon \mathrm{A}(2)-\mathrm{T}(\mathrm{II}), \epsilon \mathrm{A}(3)-\mathrm{T}(\mathrm{II})$ and $\mathrm{EA}(1)-\mathrm{T}(\mathrm{II}), \mathrm{EA}(2)-\mathrm{T}(\mathrm{II}), \mathrm{EA}(3)-\mathrm{T}(\mathrm{II})]$, have been considered with regard to their interactions. The differences in their geometrical structures, energetic properties, and hydrogen-bonding strengths have also been compared with Watson-Crick adenine-thymine base pair $(\mathrm{A}-\mathrm{T})$. Single-point energy calculations at MP2/6-311++G** levels on B3LYP/6-31+G* optimized geometries have also been carried out to better estimate the hydrogen-bonding strengths. The basis set superposition error corrected hydrogen-bonding strength sequence at MP2/6-311++G**//B3LYP/6-31+G* for the most stable complexes is found to be $\mathrm{EA}(2)-\mathrm{T}(\mathrm{I})(15.30 \mathrm{kcal} / \mathrm{mol})>\mathrm{EA}(1)-\mathrm{T}$ (II) $(14.98 \mathrm{kcal} / \mathrm{mol})$ $>\operatorname{EA}(3)-\mathrm{T}(\mathrm{II})(14.68 \mathrm{kcal} / \mathrm{mol})>\epsilon \mathrm{A}(2)-\mathrm{T}(\mathrm{I})(14.54 \mathrm{kcal} / \mathrm{mol})>\epsilon \mathrm{A}(3)-\mathrm{T}(\mathrm{II})(14.22 \mathrm{kcal} / \mathrm{mol})>\epsilon \mathrm{A}-$ (3) $-\mathrm{T}$ (II) $(13.64 \mathrm{kcal} / \mathrm{mol})>\mathrm{A}-\mathrm{T}(13.62 \mathrm{kcal} / \mathrm{mol})$. The calculated reaction enthalpy value for $\epsilon \mathrm{A}(2)-\mathrm{T}(\mathrm{I})$ is $10.05 \mathrm{kcal} / \mathrm{mol}$, which is the highest among the etheno adduct-thymine complexes and about $1.55 \mathrm{kcal} /$ mol more than those obtained for Watson-Crick A-T base pair and the reaction enthalpy value for EA(1)T(II) is $10.22 \mathrm{kcal} / \mathrm{mol}$, which is highest among the ethano addcut-thymine complexes and about $1.72 \mathrm{kcal} /$ mol more than those obtained for Watson-Crick A-T base pair. The aim of this research is to provide fundamental understanding of adenine adduct and thymine interaction at the molecular level and to aid in future experimental studies toward finding the possible cause of DNA damage.
\end{abstract}

\section{Introduction}

Endogenous lipid peroxidation products such as malondialdehyde, crotonaldehyde, and 4-hydroxy-2-nonenal are particularly potent in forming adducts during periods of oxidative stress. ${ }^{1}$ The type and quantity of fatty acids in the diet is also of significance in those trans-fatty acids, and their metabolic derivatives seem to lead to excessive formation of adducts. The initial identification of exocyclic adducts was in the 1960s; numerous studies have been reported on the identification, chemistry, and biology of various exocyclic adducts originating from both environmental and industrial sources ${ }^{2}\left[1, N^{2}\right.$-ethenodeoxyguanosine, $N^{2}$,3-ethenodeoxyguanosine $(\epsilon \mathrm{dG}), 3, N^{4}$ ethenodeoxycytidine $(\epsilon \mathrm{dC})$, and $1, N^{6}$ - ethenodeoxyadenosine $(\epsilon \mathrm{dA})$ produced by chloroethylene oxide and chloroacetaldehyde, reactive metabolites of the human carcinogen, vinyl chloride]. $\epsilon \mathrm{dA}$ and $\epsilon \mathrm{dC}$ have also been identified in mice treated with vinyl carbamate or ethyl carbamate. ${ }^{3}$ Recently, these two adducts were shown to exist in liver DNA of untreated rats and humans, ${ }^{4}$ suggesting their formation from certain endogenous sources. In fact, Ghissassi et al. ${ }^{5}$ have shown that lipid peroxidation products cause the formation of $\epsilon \mathrm{dA}$ and $\epsilon \mathrm{dC}$. The levels of DNA adducts in human leucocytes has been found to vary with a number of lifestyle, environmental, and chemical-exposure factors. Cancers with poorly defined etiology may be explained once DNA adducts are identified. It has been reported that the existence of DNA adducts bring the danger of carcinogenesis because of mispairing with normal DNA bases. ${ }^{4}$ Exocyclic DNA adducts are a unique class of ring-extended modifications ${ }^{6}$ formed by a

* Corresponding author. E-mail: chesll@ccu.edu.tw. wild range of chemicals. DNA adducts play a role in vinyl chloride induced tumorigenisis. ${ }^{7}$ DNA adducts are also implicated in many types of human cancer, especially where persistent oxidative stress leads to malignancy by increasing mutations and genomic instability at the DNA level. The detection of DNA adducts as promutagenic markers enables, in some patients, an understanding of cancer risk. It also defines and promotes active intervention measures aimed at reducing exposure to the offending chemicals or moderation of the endogenous processes responsible for some adducts. This is particularly so where the level of and destructive activity of metal adducts can be reduced by the use of nutritionally important.

It would be a great subject of interest to study the interaction of $1, N^{6}$-ethenoadenine adducts $(\epsilon \mathrm{A})$ and $1, N^{6}$-ethanoadenine adducts (EA) as DNA adducts and thymine as nucleic acid base. $1, N^{6}$-Ethanoadenine adducts differ from etheno adducts by the change of a double to a single bond in a five-member exocyclic ring and are formed by chloroethyl nitrosoureas, which are used in cancer therapy. ${ }^{8}$ The intrinsic mutagenic potential of $1, N^{6}$ ethenoadenine adduct has been investigated in Esherichia coli (E. coli) and mammalian cells. ${ }^{9}$ Experimentally, it has been shown that $\epsilon \mathrm{A}$ is highly mutagenic. ${ }^{10} \mathrm{We}$ would like to investigate the changes for the gas phase of interaction in $\epsilon \mathrm{A}-\mathrm{T}$ and EA-T complexes, including different structures. It may provide a possible cause for DNA damage and aid in future experimental studies toward the understanding of the adenine adduct-thymine complexes $(\epsilon \mathrm{A}-\mathrm{T}, \mathrm{EA}-\mathrm{T})$.

In our work, we have considered many different positions of interactions between adenine adducts and thymine, $[\epsilon \mathrm{A}(1)-\mathrm{T}(\mathrm{I})$, $\epsilon \mathrm{A}(2)-\mathrm{T}(\mathrm{I}), \epsilon \mathrm{A}(3)-\mathrm{T}(\mathrm{I})$ and $\mathrm{EA}(1)-\mathrm{T}(\mathrm{I}), \mathrm{EA}(2)-\mathrm{T}(\mathrm{I}), \mathrm{EA}-$ 
SCHEME 1: Interacting Parts Considered for the Adenine Adducts $(\epsilon A$ and EA) and Thymine in Our Study

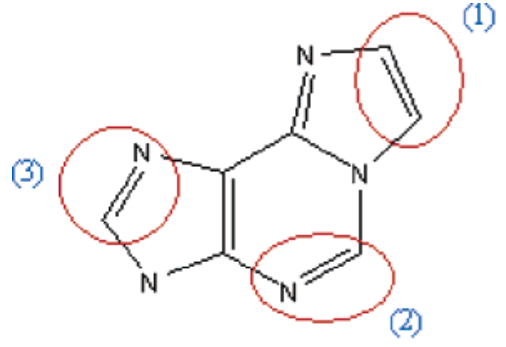

etheno-adenine ( $\varepsilon A)$

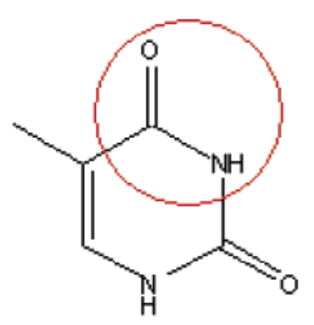

thymine (I)

(3) $-\mathrm{T}(\mathrm{I})]$ and $[\epsilon \mathrm{A}(1)-\mathrm{T}(\mathrm{II}), \epsilon \mathrm{A}(2)-\mathrm{T}(\mathrm{II}), \epsilon \mathrm{A}(3)-\mathrm{T}(\mathrm{II})$ and $\mathrm{EA}-$ (1)-T(II), EA(2)-T(II), EA(3)-T(II)] (Scheme 1), and compared the difference in their geometrical structures, energetic properties, and hydrogen-bonding strengths with Watson-Crick adenine-thymine base pair $(\mathrm{A}-\mathrm{T})$. It is also insightful since it provides a fundamental understanding of adenine adduct and thymine interaction at the molecular level.

In recent years, so as to understand the various biochemical processes including point mutation, several studies on tautomeric equilibria of nucleic acid bases and their interaction with ions in the gas phase have been reported. ${ }^{11-18}$ However, the biochemical process is predominantly a solution-based discipline with water providing the ubiquitous solvent. We are aware of such a solvent effect, which will be the aim of our future projects.

\section{Computational Methods}

The geometry and harmonic vibrational frequencies of $\epsilon \mathrm{A}$, EA, thymine, and the resulted different possible geometries for $\epsilon \mathrm{A}$-thymine complexes and EA - thymine complexes have been calculated using density functional theory (DFT) method with the Pople type split valence basis set $\left(6-31+\mathrm{G}^{*}\right)$. For hydrogenbonded systems, it is expected that both diffuse and polarization function are necessary in the basis set. B3LYP ${ }^{19-22}$ is chosen as density functional for this study. This is a hybrid functional consisting of Becke's exchange functional, the Lee-YangParr correlation functional, and a Hartree-Fock exchange term. DFT has been successfully used to study hydrogen-bonded complexes, ${ }^{23-31}$ even the most weakly bound systems. ${ }^{32}$ Besides, previous DFT studies ${ }^{29-31,33}$ clarified that one has to apply gradient correction in both the exchange and the correlation part of the potential to get meaningful results in the intermolecular framework. Hybrid DFT functionals, such as B3LYP, by their very nature, already include a part of correct asymptotics via Hartree-Fock exchange, which improves the overall asymptotic behavior of these functionals. Single-point energy calculations at the MP2/6-311++G** levels on B3LYP optimized geometries have also been carried out to better estimate the hydrogenbonding strengths. The calculated hydrogen-bonding energies
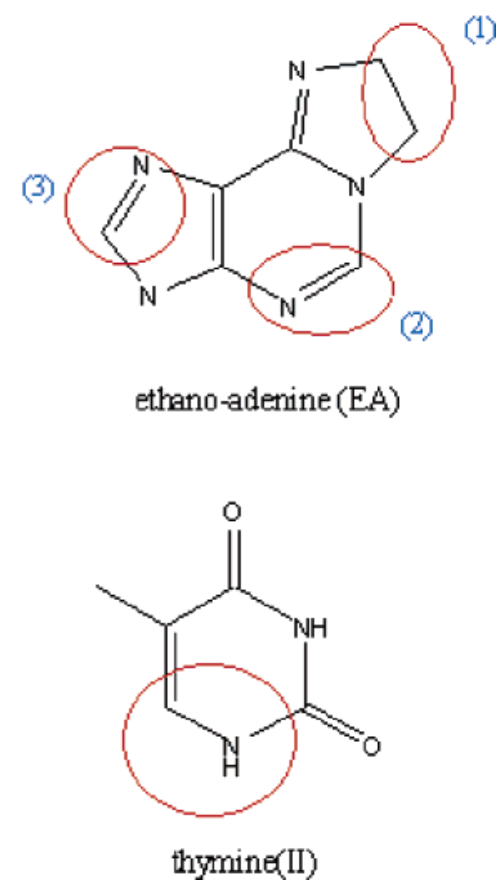

are corrected for the basis set superposition error (BSSE), using counterpoise method. ${ }^{34}$ The electronic structure calculations have been performed using the GAUSSIAN 03 program. ${ }^{35}$

\section{Results and Discussion}

(a) Optimized Geometries Parameters for DNA AdductThymine Complexes. The B3LYP/6-31+G* optimized structure for the etheno adenine-thymine(I) complexes are shown in Figure $1 \mathrm{a}-\mathrm{c}$, whereas the ethano adenine-thymine(I) complexes are shown in Figure $2 \mathrm{a}-\mathrm{c}$. Optimized structures of etheno adenine-thymine(II) and ethano adenine-thymine(II) complexes are shown in Figure $3 a-c$ and Figure $4 a-c$, respectively.

The optimized parameters for the Watson-Crick A-T complex and corresponding monomers using the B3LYP/6$31+\mathrm{G}^{*}$ method have been computed (cf. Suppporting Information Table 1a). A great deal of experimental as well as theoretical work has been carried out to investigate the structure and energetics of the $\mathrm{A}-\mathrm{T}$ base pair so as to determine the effects of Watson-Crick type hydrogen bonding and its tautomeric transitions on the vibrational spectra of the nucleic acid bases, adenine and thymine. Since we are going to compare the differences in the geometrical structures, energetic properties, and hydrogen-bonding strengths of our current study for the interaction of adenine adducts, $\epsilon \mathrm{A}$ and EA with thymine, we would like to compare our computed structural parameters for $\mathrm{A}-\mathrm{T}$ base pair, with reference to previous experimental and theoretical observations ${ }^{11,36-42}$ (cf. Supporting Information Table 1b). The computed hydrogen bond lengths show the notorious discrepancy with experimental values. The source of divergence seems to be the molecular environment (water, sugar hydroxyl groups, and counter ions) of the base pairs in the crystals studied experimentally. This has been missing, so far in all theoretical models; however, by using B3LYP/6-31+G*, our computed data exhibit superior results to those obtained with HF methods ${ }^{38-40}$ and comparative to those obtained with previous DFT study. ${ }^{11,41,42}$ The calculated geometry parameters for the complexes $\epsilon \mathrm{A}(1)-\mathrm{T}(\mathrm{I}), \epsilon \mathrm{A}(2)-\mathrm{T}(\mathrm{I})$, and $\epsilon \mathrm{A}(3)-\mathrm{T}(\mathrm{I})$ and the corresponding monomers $\epsilon \mathrm{A}$ and $\mathrm{T}$ (cf. Supporting Information 

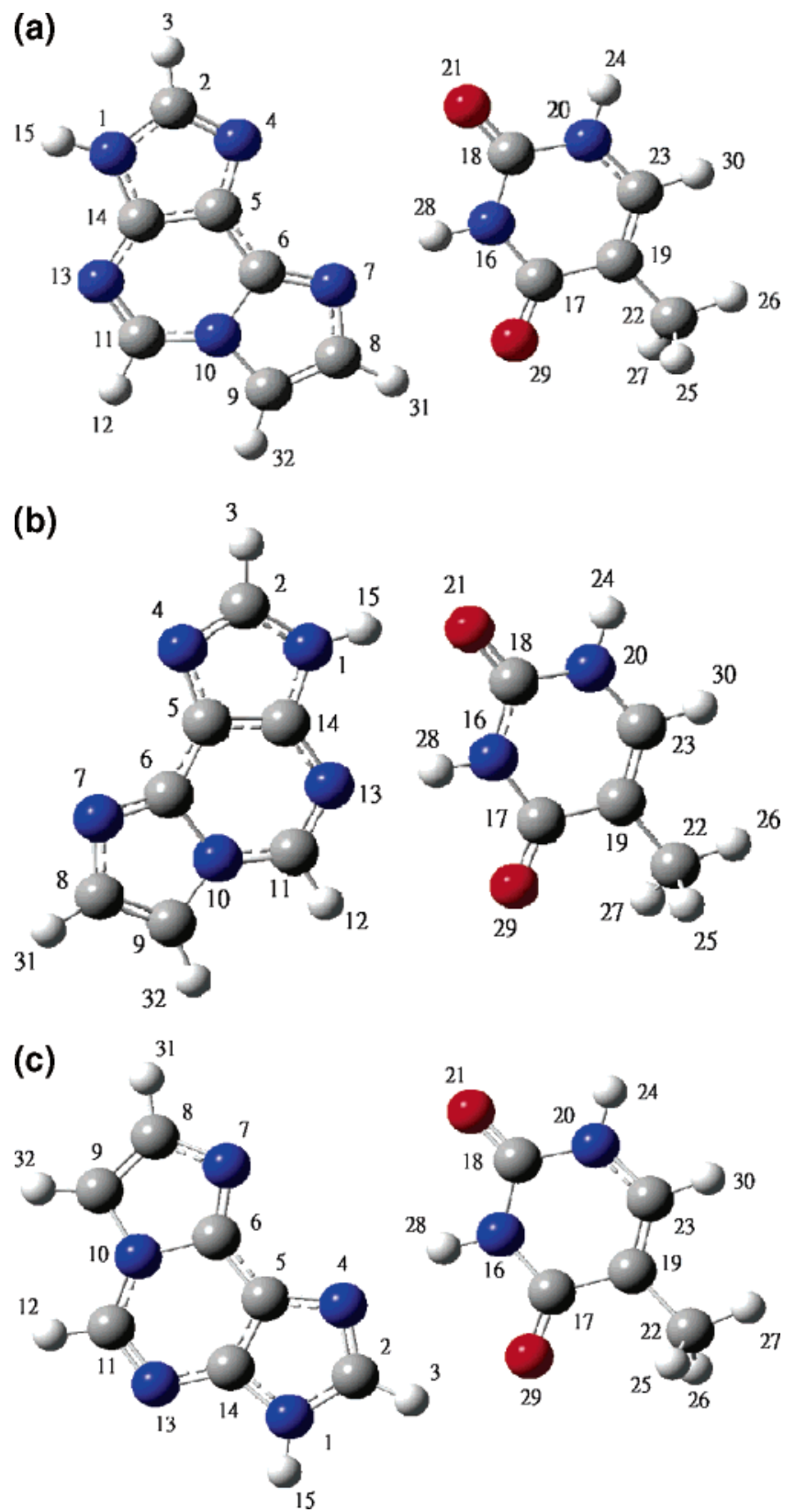

Figure 1. (a, top) Optimized structure of $\epsilon \mathrm{A}(1)-\mathrm{T}(\mathrm{I})$ complex. (b, middle) Optimized structure of $\epsilon \mathrm{A}(2)-\mathrm{T}(\mathrm{I})$ complex. (c, bottom) Optimized structure of $\epsilon \mathrm{A}(3)-\mathrm{T}(\mathrm{I})$ complex.

Table 2a) reveal that the bond length $\mathrm{N}_{16}-\mathrm{H}_{28}$, which is involved in hydrogen bonding for all three complexes $\epsilon \mathrm{A}(1)-$ $\mathrm{T}(\mathrm{I}), \epsilon \mathrm{A}(2)-\mathrm{T}(\mathrm{I})$, and $\epsilon \mathrm{A}(3)-\mathrm{T}(\mathrm{I})$, is observed to increase around $0.02 \AA$ as compared to that for the thymine monomer. In the $\epsilon \mathrm{A}(2)-\mathrm{T}(\mathrm{I})$ complex, the bond length $\mathrm{N}_{1}-\mathrm{H}_{15}$ is involved in second hydrogen bonding also found to be $1.025 \AA$ as compared to those of $1.011 \AA$ for the $\epsilon \mathrm{A}$ monomer. The bond angle $\angle \mathrm{C}_{18} \mathrm{~N}_{16} \mathrm{C}_{17}$ of thymine monomer is found to be decreased from 128.0 to $126.8^{\circ}$, to $127.0^{\circ}$, and to $126.8^{\circ}$ for all three complexes $\epsilon \mathrm{A}(1)-\mathrm{T}(\mathrm{I}), \epsilon \mathrm{A}(2)-\mathrm{T}(\mathrm{I})$, and $\epsilon \mathrm{A}(3)-\mathrm{T}(\mathrm{I})$, after complexation, respectively. Conversely, the bond angles $\angle \mathrm{C} 6 \mathrm{~N} 7 \mathrm{C} 8, \angle \mathrm{C} 11 \mathrm{~N} 13 \mathrm{C} 14$, and $\angle \mathrm{C} 2 \mathrm{~N} 4 \mathrm{C} 5$ are found to be increased slightly for $\epsilon \mathrm{A}(1)-\mathrm{T}(\mathrm{I}), \epsilon \mathrm{A}(2)-\mathrm{T}(\mathrm{I})$, and $\epsilon \mathrm{A}(3)-\mathrm{T}(\mathrm{I})$, respectively, and $\angle \mathrm{C} 14 \mathrm{~N} 1 \mathrm{C} 2$ found to be decreased $\sim 1^{\circ}$ as compared to those of the $\epsilon \mathrm{A}$ monomer. The calculated geometry parameters for the complexes EA(1)-T(I), EA(2)-T(I), and EA(3)-T(I) and the corresponding monomers EA and T (cf. Supporting Information Table $2 \mathrm{~b}$ ) also show that the bond length
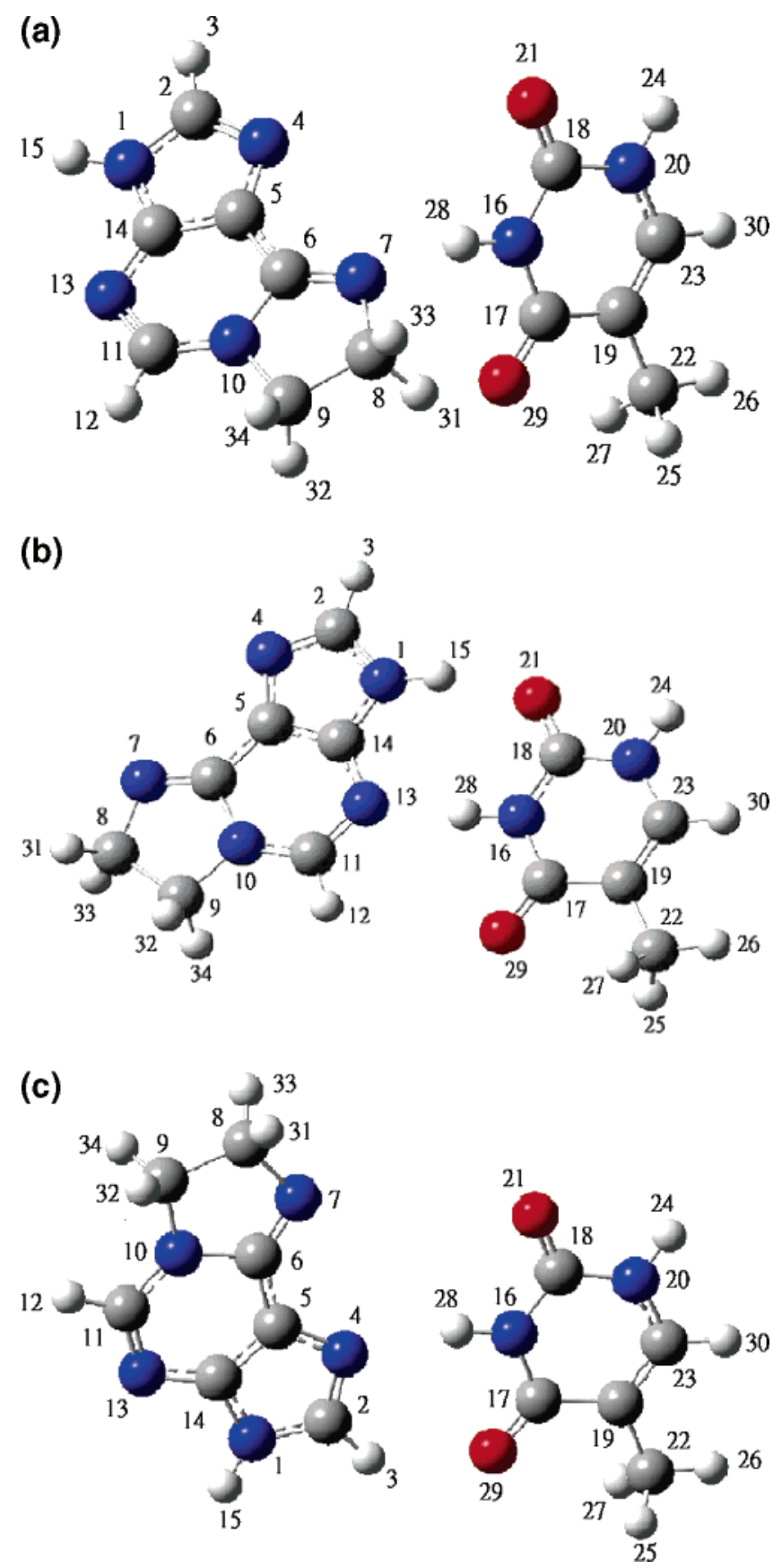

Figure 2. (a, top) Optimized structure of EA(1)-T(I) complex. (b, middle) Optimized structure of EA(2)-T(I) complex. (c, bottom) Optimized structure of EA(3)-T(I) complex.

$\mathrm{N}_{16}-\mathrm{H}_{28}$, involved in hydrogen bonding for all three complexes $\mathrm{EA}(1)-\mathrm{T}(\mathrm{I}), \mathrm{EA}(2)-\mathrm{T}(\mathrm{I})$, and $\mathrm{EA}(3)-\mathrm{T}(\mathrm{I})$, is observed to be increased around $0.023,0.026$, and $0.019 \AA$, respectively, as compared to that of the thymine monomer. In the EA(1)-T(I) complex, the bond lengths C6-N7, N7-C8, and C17-O29 are also found to be slightly increased compared to bare EA and thymine, respectively. In the $\mathrm{EA}(2)-\mathrm{T}(\mathrm{I})$ complex, the bond length $\mathrm{N} 1-\mathrm{H} 15$, which is also involved in second hydrogenbonding, was found to be $1.024 \AA$ as compared to that of 1.011 $\AA$ for the EA monomer. After complexation, the bond angle $\angle \mathrm{C}_{18} \mathrm{~N}_{16} \mathrm{C}_{17}$ of the thymine monomer is found to be decreased from 128.0 to $126.8^{\circ}$, to $126.9^{\circ}$, and to $126.7^{\circ}$ for all three complexes EA(1)-T(I), EA(2)-T(I), and EA(3)-T(I), respectively. Conversely, the bond angles $\angle \mathrm{C} 6 \mathrm{~N} 7 \mathrm{C} 8, \angle \mathrm{C} 11 \mathrm{~N} 13 \mathrm{C} 14$, and $\angle \mathrm{C} 2 \mathrm{~N} 4 \mathrm{C} 5$ are found to be increased slightly for $\mathrm{EA}(1)-$ 
(a)

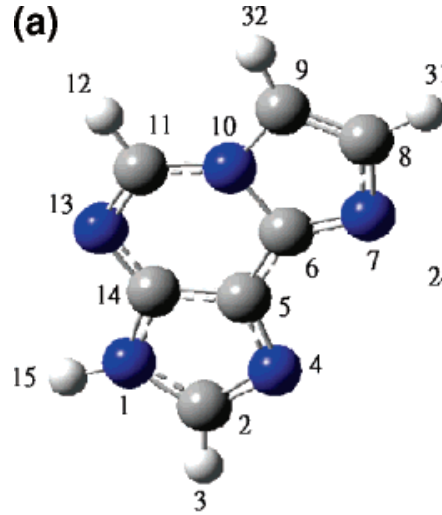

(b)
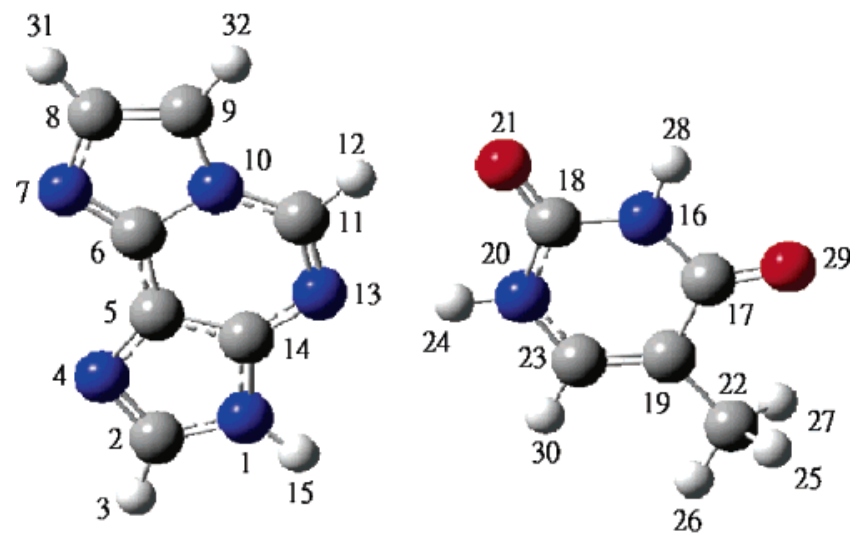

(c)
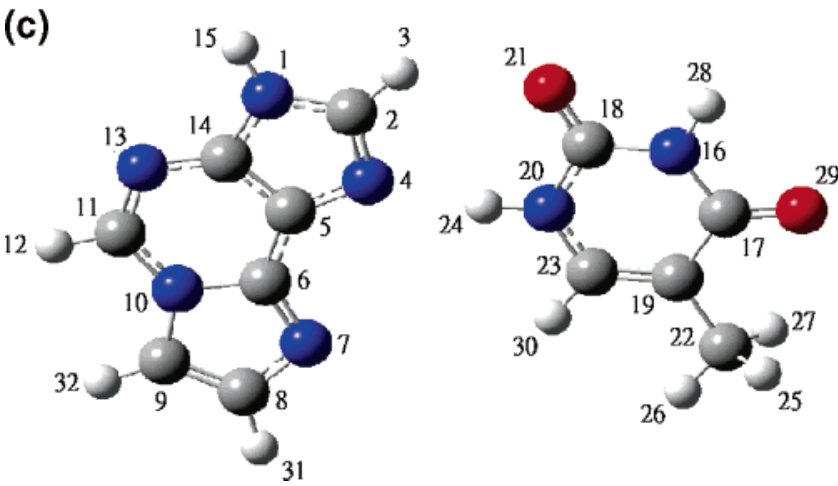

Figure 3. (a, top) Optimized structure of $\epsilon \mathrm{A}(1)-\mathrm{T}(\mathrm{II})$ complex. (b, middle) Optimized structure of $\epsilon \mathrm{A}(2)-\mathrm{T}(\mathrm{II})$ complex. (c, bottom) Optimized structure of $\epsilon \mathrm{A}(3)-\mathrm{T}(\mathrm{II})$ complex.

$\mathrm{T}(\mathrm{I}), \mathrm{EA}(2)-\mathrm{T}(\mathrm{I})$, and $\mathrm{EA}(3)-\mathrm{T}(\mathrm{I})$, respectively, and $\angle \mathrm{C} 14 \mathrm{~N} 1 \mathrm{C} 2$ for $\mathrm{EA}(2)-\mathrm{T}$ found to be decreased $\sim 0.6^{\circ}$ as compared to bare EA.

The calculated geometry parameters for the complexes $\epsilon \mathrm{A}$ (1) $-\mathrm{T}(\mathrm{II}), \epsilon \mathrm{A}(2)-\mathrm{T}(\mathrm{II})$, and $\epsilon \mathrm{A}(3)-\mathrm{T}(\mathrm{II})$ and the corresponding monomers $\epsilon \mathrm{A}$ and $\mathrm{T}$ (cf. Supporting Information Table 2c) exhibit that the bond length $\mathrm{N}_{20}-\mathrm{H}_{24}$, involved in hydrogen bonding for all three complexes $\epsilon \mathrm{A}(1)-\mathrm{T}(\mathrm{II}), \epsilon \mathrm{A}(2)-\mathrm{T}(\mathrm{II})$, and $\epsilon \mathrm{A}(3)-\mathrm{T}(\mathrm{II})$, is observed to increase around $0.021,0.015$, and $0.020 \AA$, respectively, as compared to that of the thymine(II) monomer. In $\epsilon \mathrm{A}(1)-\mathrm{T}(\mathrm{II})$ complex and $\epsilon \mathrm{A}(2)-\mathrm{T}$ (II) complex, the bond length $\mathrm{C} 18-\mathrm{O} 21$ is found to be 1.228 and $1.229 \AA$, respectively, compared to $1.221 \AA$ of bare thymine. In $\epsilon \mathrm{A}(3)-$ T(II) complex, the bond lengths $\mathrm{C} 18-\mathrm{O} 21$ and $\mathrm{C} 2-\mathrm{N} 4$ are found to be 1.231 and $1.322 \AA$, compared to 1.221 and 1.316 $\AA$ of bare thymine(II) and $\epsilon \mathrm{A}$, respectively. After complexation, the bond angle $\angle \mathrm{C}_{23} \mathrm{~N}_{20} \mathrm{C}_{18}$ of the thymine monomer is found to be decreased from 123.8 to $123.2^{\circ}$, to $122.9^{\circ}$, and to $123.1^{\circ}$ for all three complexes $\epsilon \mathrm{A}(1)-\mathrm{T}(\mathrm{II}), \epsilon \mathrm{A}(2)-\mathrm{T}(\mathrm{II})$, and $\epsilon \mathrm{A}(3)-$

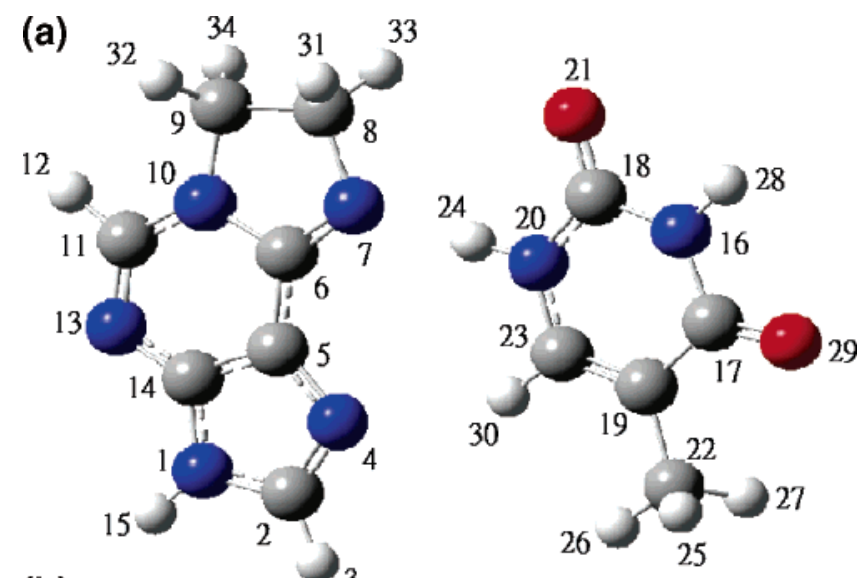

(b)
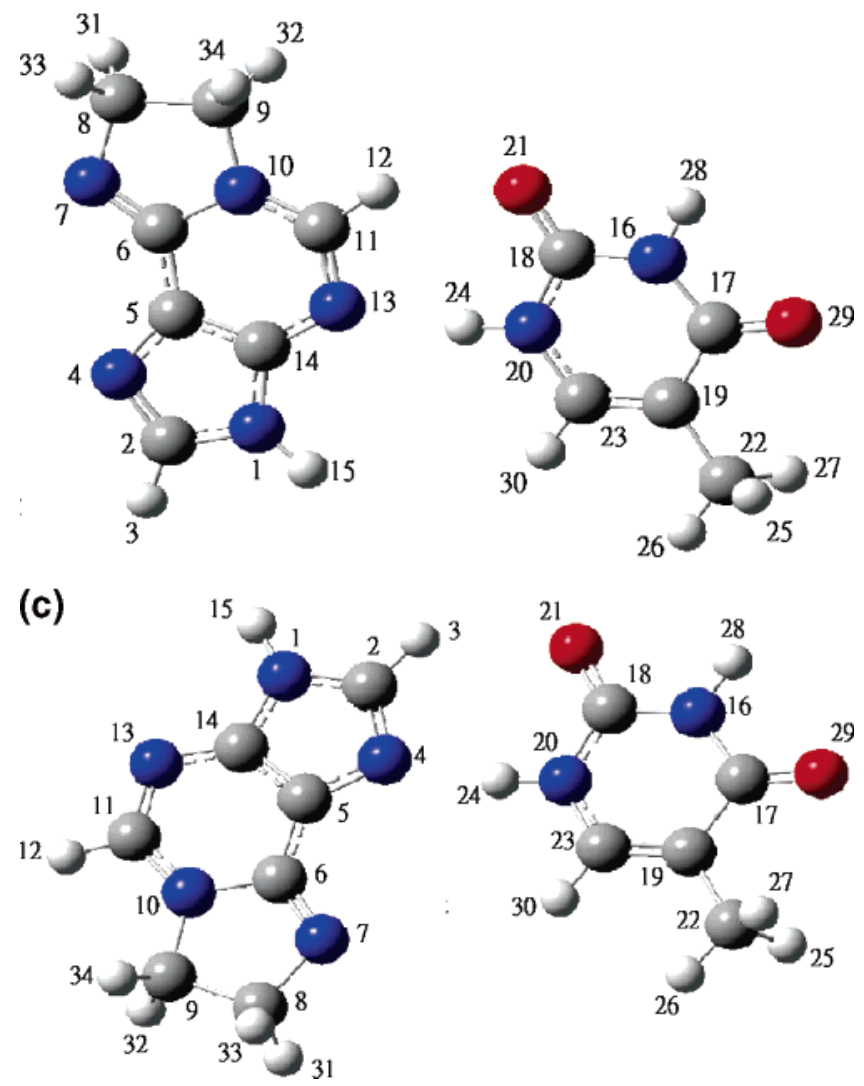

Figure 4. (a, top) Optimized structure of EA(1)-T(II) complex. (b, middle) Optimized structure of $\mathrm{EA}(2)-\mathrm{T}(\mathrm{II})$ complex. (c, bottom) Optimized structure of EA(3)-T(II) complex.

$\mathrm{T}(\mathrm{II})$, respectively. Conversely, the bond angles $\angle \mathrm{C} 6 \mathrm{~N} 7 \mathrm{C} 8$, $\angle \mathrm{C} 11 \mathrm{~N} 13 \mathrm{C} 14$, and $\angle \mathrm{C} 2 \mathrm{~N} 4 \mathrm{C} 5$ are found to increase around $\sim 1.0^{\circ}$ for $\epsilon \mathrm{A}(1)-\mathrm{T}(\mathrm{II}), \epsilon \mathrm{A}(2)-\mathrm{T}(\mathrm{II})$, and $\epsilon \mathrm{A}(3)-\mathrm{T}(\mathrm{II})$, respectively. The calculated geometry parameters for the complexes $\mathrm{EA}(1)-\mathrm{T}(\mathrm{II}), \mathrm{EA}(2)-\mathrm{T}(\mathrm{II})$, and $\mathrm{EA}(3)-\mathrm{T}(\mathrm{II})$ and the corresponding monomers EA and T(II) (cf. Supporting Information Table 2d) show that the bond length $\mathrm{N}_{20}-\mathrm{H}_{24}$, involved in hydrogen bonding for all the three complexes EA(1)-T(II), EA(2) $-\mathrm{T}(\mathrm{II})$, and $\mathrm{EA}(3)-\mathrm{T}(\mathrm{II})$, is observed to increase around $0.022,0.019$, and $0.022 \AA$, respectively, as compared to that of the thymine(II) monomer. After complexation, the bond angle $\angle \mathrm{C}_{23} \mathrm{~N}_{20} \mathrm{C}_{18}$ of the thymine monomer is found to decrease from 123.8 to $123.3^{\circ}$, to $122.8^{\circ}$, and to $123.2^{\circ}$ for all three complexes $\mathrm{EA}(1)-\mathrm{T}(\mathrm{II}), \mathrm{EA}(2)-\mathrm{T}(\mathrm{II})$, and $\mathrm{EA}(3)-\mathrm{T}(\mathrm{II})$, respectively. Conversely, the bond angles $\angle \mathrm{C} 6 \mathrm{~N} 7 \mathrm{C} 8, \angle \mathrm{C} 11 \mathrm{~N} 13 \mathrm{C} 14$, and $\angle \mathrm{C} 2 \mathrm{~N} 4 \mathrm{C} 5$ are found to increase $\sim 1.0^{\circ}$ for $\mathrm{EA}(1)-\mathrm{T}(\mathrm{II})$, EA(2)-T(II), and $\mathrm{EA}(3)-\mathrm{T}(\mathrm{II})$, respectively. 
TABLE 1: Hydrogen Bond Lengths $(\AA)$ and Bond Angles (deg) for Adenine Adduct-Thymine Complexes Using B3LYP/6-31+G*

\begin{tabular}{|c|c|c|c|c|c|}
\hline parameter & $\epsilon \mathrm{A}(1)-\mathrm{T}(\mathrm{I})$ & $\mathrm{EA}(1)-\mathrm{T}(\mathrm{I})$ & parameter & $\epsilon \mathrm{A}(1)-\mathrm{T}(\mathrm{II})$ & $\mathrm{EA}(1)-\mathrm{T}(\mathrm{II})$ \\
\hline $\mathrm{N} 7-\mathrm{H} 28$ & 2.018 & 1.931 & $\mathrm{~N} 7-\mathrm{H} 24$ & 1.881 & 1.892 \\
\hline \multirow[t]{2}{*}{$\mathrm{H} 31-\mathrm{O} 29$} & 2.329 & 2.541 & $\mathrm{H} 31-\mathrm{O} 21$ & 2.726 & 3.660 \\
\hline & & & $\mathrm{N} 4-\mathrm{H} 30$ & - & 2.691 \\
\hline$\angle \mathrm{N} 7 \mathrm{H} 28 \mathrm{~N} 16$ & 165.7 & 164.7 & $\angle \mathrm{N} 7 \mathrm{H} 24 \mathrm{~N} 20$ & 173.7 & 178.5 \\
\hline \multirow[t]{2}{*}{$\angle \mathrm{C} 8 \mathrm{H} 31 \mathrm{O} 29$} & 128.5 & 133.7 & $\angle \mathrm{C} 8 \mathrm{H} 31 \mathrm{O} 21$ & 127.9 & 94.5 \\
\hline & & & $\angle \mathrm{N} 4 \mathrm{H} 30 \mathrm{C} 23$ & - & 151.7 \\
\hline parameter & $\epsilon \mathrm{A}(2)-\mathrm{T}(\mathrm{I})$ & $\mathrm{EA}(2)-\mathrm{T}(\mathrm{I})$ & parameter & $\epsilon \mathrm{A}(2)-\mathrm{T}(\mathrm{II})$ & $\mathrm{EA}(2)-\mathrm{T}(\mathrm{II})$ \\
\hline $\mathrm{N} 13-\mathrm{H} 28$ & 1.923 & 1.881 & $\mathrm{~N} 13-\mathrm{H} 24$ & 2.024 & 1.970 \\
\hline $\mathrm{H} 15-\mathrm{O} 21$ & 1.907 & 1.921 & $\mathrm{H} 12-\mathrm{O} 21$ & 2.219 & 2.234 \\
\hline$\angle \mathrm{N} 13 \mathrm{H} 28 \mathrm{~N} 16$ & 175.2 & 175.6 & $\angle \mathrm{N} 13 \mathrm{H} 24 \mathrm{~N} 20$ & 169.5 & 170.3 \\
\hline$\angle \mathrm{N} 1 \mathrm{H} 15 \mathrm{O} 21$ & 161.9 & 161.8 & $\angle \mathrm{C} 11 \mathrm{H} 12 \mathrm{O} 21$ & 146.2 & 146.0 \\
\hline parameter & $\epsilon \mathrm{A}(3)-\mathrm{T}(\mathrm{I})$ & $\mathrm{EA}(3)-\mathrm{T}(\mathrm{I})$ & parameter & $\epsilon \mathrm{A}(3)-\mathrm{T}(\mathrm{II})$ & $\mathrm{EA}(3)-\mathrm{T}(\mathrm{II})$ \\
\hline $\mathrm{N} 4-\mathrm{H} 28$ & 2.044 & 2.035 & $\mathrm{~N} 4-\mathrm{H} 24$ & 1.903 & 1.880 \\
\hline $\mathrm{H} 3-\mathrm{O} 29$ & 2.223 & 2.243 & $\mathrm{H} 3-\mathrm{O} 21$ & 2.396 & 2.482 \\
\hline$\angle \mathrm{N} 4 \mathrm{H} 28 \mathrm{~N} 16$ & 163.7 & 163.8 & $\angle \mathrm{N} 4 \mathrm{H} 24 \mathrm{~N} 20$ & 167.8 & 169.1 \\
\hline$\angle \mathrm{C} 2 \mathrm{H} 3 \mathrm{O} 29$ & 135.3 & 134.3 & $\angle \mathrm{C} 2 \mathrm{H} 3 \mathrm{O} 21$ & 130.3 & 128.0 \\
\hline
\end{tabular}

However, significant changes in the dihedral angles for ethano-adenine-thymine complex (cf. Supporting Information Table 2b,d) have also been observed after complexation, whereas, for the etheno-adenine adduct, the dihedral bond angles remain unaltered (cf. Supporting Information Table 2a,c). Due to the presence of the more flexible exocyclic ring including four hydrogen atoms in the ethano-adenine adduct, thymine acts on ring accessibly, as a result of the dihedral angles; $\angle \mathrm{C} 6 \mathrm{~N} 7 \mathrm{C} 8 \mathrm{C} 9, \angle \mathrm{N} 7 \mathrm{C} 8 \mathrm{C} 9 \mathrm{~N} 10, \angle \mathrm{H} 31 \mathrm{C} 8 \mathrm{C} 9 \mathrm{~N} 10, \angle \mathrm{H} 32 \mathrm{C} 9 \mathrm{C} 8 \mathrm{~N} 7$, $\angle \mathrm{H} 33 \mathrm{C} 8 \mathrm{C} 9 \mathrm{~N} 10$, and $\angle \mathrm{H} 34 \mathrm{C} 9 \mathrm{C} 8 \mathrm{~N} 7$ have remarkable changes as compared to bare EA, after complexation with thymine (cf. Supporting Information Table 2b,d).

(b) Hydrogen-Bonding Parameters for DNA AdductThymine Complexes. The optimized hydrogen bond distances and bond angles for the adenine adduct and thymine complexes, $[\epsilon \mathrm{A}(1)-\mathrm{T}(\mathrm{I}), \epsilon \mathrm{A}(2)-\mathrm{T}(\mathrm{I}), \epsilon \mathrm{A}(3)-\mathrm{T}(\mathrm{I})$ and $\mathrm{EA}(1)-\mathrm{T}(\mathrm{I}), \mathrm{EA}-$ $(2)-\mathrm{T}(\mathrm{I}), \mathrm{EA}(3)-\mathrm{T}(\mathrm{I})]$ and $[\epsilon \mathrm{A}(1)-\mathrm{T}(\mathrm{II}), \epsilon \mathrm{A}(2)-\mathrm{T}(\mathrm{II}), \epsilon \mathrm{A}(3)-$ $\mathrm{T}(\mathrm{II})$ and $\mathrm{EA}(1)-\mathrm{T}(\mathrm{II}), \mathrm{EA}(2)-\mathrm{T}(\mathrm{II}), \mathrm{EA}(3)-\mathrm{T}(\mathrm{II})]$, are cited in Table 1. The hydrogen bond is a unique phenomenon in structural chemistry and biology. Its fundamental importance lies in its role in molecular association and is considered as an important factor in stabilizing bimolecular structures. From Table 1, it can be observed that the hydrogen bond lengths N7$\mathrm{H} 28$ and $\mathrm{O} 29-\mathrm{H} 31$ in $\epsilon \mathrm{A}(1)-\mathrm{T}(\mathrm{I})$ complex are found to be 2.018 and $2.329 \AA$, respectively, and in $\mathrm{EA}(1)-(\mathrm{T})$ complex, 1.931 and $2.541 \AA$, respectively. For $\epsilon \mathrm{A}(1)-\mathrm{T}(\mathrm{I})$ and $\mathrm{EA}(1)-$ $\mathrm{T}(\mathrm{I})$ complexes, the bond angle $\angle \mathrm{N} 7 \mathrm{H} 28 \mathrm{~N} 16$ is found to be 165.7 and $164.7^{\circ}$, whereas the bond angle $\angle \mathrm{C} 8 \mathrm{H} 31 \mathrm{O} 29$ is found to be 128.5 and $133.7^{\circ}$, respectively. The hydrogen bond lengths $\mathrm{N} 13-\mathrm{H} 28$ and $\mathrm{O} 21-\mathrm{H} 15$ are found to be 1.923 and $1.907 \AA$ in $\epsilon \mathrm{A}(2)-\mathrm{T}(\mathrm{I})$ complex and 1.881 and $1.921 \AA$ in $\mathrm{EA}(2)-\mathrm{T}(\mathrm{I})$ complex, respectively. The corresponding bond angles $\angle \mathrm{N} 13 \mathrm{H} 28 \mathrm{~N} 16$ (175.2 and $\left.175.6^{\circ}\right)$ and $\angle \mathrm{N} 1 \mathrm{H} 15 \mathrm{O} 21\left(161.9\right.$ and $\left.161.8^{\circ}\right)$ for these complexes are found to be nearly the same. In $\epsilon \mathrm{A}(3)-$ $\mathrm{T}(\mathrm{I})$ and $\mathrm{EA}(3)-\mathrm{T}(\mathrm{I})$ complexes, the hydrogen bond lengths N4-H28 and O29-H3 are found to be 2.044 and $2.223 \AA$, and 2.035 and $2.243 \AA$, respectively, and the corresponding bond angles are found to be $\angle \mathrm{N} 7 \mathrm{H} 28 \mathrm{~N} 16$ (163.7 and $\left.163.8^{\circ}\right)$ and $\angle \mathrm{C} 8 \mathrm{H} 31 \mathrm{O} 29\left(135.3\right.$ and $\left.134.3^{\circ}\right)$, respectively. On comparing the $\epsilon \mathrm{A}(1)-\mathrm{T}(\mathrm{I}), \epsilon \mathrm{A}(2)-\mathrm{T}(\mathrm{I})$, and $\epsilon \mathrm{A}(3)-\mathrm{T}(\mathrm{I})$ complexes, the hydrogen bond lengths $(\mathrm{N}-\mathrm{H} \cdots \mathrm{N}$ and $\mathrm{N}-\mathrm{H} \cdots \mathrm{O})$ found for $\epsilon \mathrm{A}-$ (2) $-\mathrm{T}(\mathrm{I})$ complex were observed to be shorter, having more linear corresponding bond angles, indicating strong interaction among the three different complexes. On the other hand, similar to the etheno-adenine adduct-thymine complex, among the three different ethano-adenine adduct-thymine complexes EA(1) - T(I), EA(2)-T(I), and EA(3)-T(I), the EA(2)-T(I) complex has shorter hydrogen bond lengths $(\mathrm{N}-\mathrm{H} \cdots \mathrm{N}$ and $\mathrm{N}-\mathrm{H} \cdots \mathrm{O}$ ) and the corresponding bond angles are more linear, associated with strong interaction (details about the interaction energy will be discussed in the next section).

Table 1 also depicts that the hydrogen bond length N7-H24 is found to be approximately the same (1.881 and $1.892 \AA$ ) for the $\epsilon \mathrm{A}(1)-\mathrm{T}(\mathrm{II})$ and $\mathrm{EA}(1)-\mathrm{T}(\mathrm{II})$ complexes, respectively, whereas $\mathrm{O} 29-\mathrm{H} 31$ is found to be $2.726 \AA$ for $\epsilon \mathrm{A}(1)-\mathrm{T}(\mathrm{II})$ complex and N4-H30 is found to be $2.691 \AA$ for EA(1)-T(II) complex. The corresponding bond angles $\angle \mathrm{N} 7 \mathrm{H} 24 \mathrm{~N} 20$ are 173.7 and $178.5^{\circ}$ for $\epsilon \mathrm{A}(1)-\mathrm{T}(\mathrm{II})$ and $\mathrm{EA}(1)-\mathrm{T}(\mathrm{II})$ complexes, respectively, whereas $\angle \mathrm{C} 8 \mathrm{H} 31 \mathrm{O} 29$ is found to be $127.9^{\circ}$ for $\epsilon \mathrm{A}(1)-\mathrm{T}(\mathrm{II})$ and $\angle \mathrm{N} 4 \mathrm{H} 30 \mathrm{C} 23$ is found to be $151.7^{\circ}$ for EA(1) $-\mathrm{T}(\mathrm{II})$. In $\in \mathrm{A}(2)-\mathrm{T}(\mathrm{II})$ and $\mathrm{EA}(2)-\mathrm{T}(\mathrm{II})$ complexes, the hydrogen bond lengths are N13-H24 (2.024 and $1.970 \AA$, respectively) and $\mathrm{O} 21-\mathrm{H} 12$ (2.219 and $2.234 \AA$, respectively) and the corresponding bond angles $\angle \mathrm{N} 13 \mathrm{H} 24 \mathrm{~N} 20$ (169.5 and $170.3^{\circ}$, respectively) and $\angle \mathrm{C} 11 \mathrm{H} 121 \mathrm{O} 21$ are found to be approximately the same $\left(146.2\right.$ and $\left.146.0^{\circ}\right)$. The hydrogen bond lengths in $\epsilon \mathrm{A}(3)-\mathrm{T}(\mathrm{II})$ and $\mathrm{EA}(3)-\mathrm{T}(\mathrm{II})$ complexes are N4H24 (1.903 and $1.880 \AA$, respectively) and O21-H3 (2.396 and $2.482 \AA$, respectively) and the corresponding bond angles are $\angle \mathrm{N} 4 \mathrm{H} 24 \mathrm{~N} 20$ (167.8 and $169.1^{\circ}$, respectively) and $\angle \mathrm{C} 2 \mathrm{H} 3 \mathrm{O} 21$, found to be 130.3 and $128.0^{\circ}$, respectively. On comparing the three different complexes $\epsilon \mathrm{A}(1)-\mathrm{T}(\mathrm{II}), \epsilon \mathrm{A}(2)-\mathrm{T}(\mathrm{II})$, and $\epsilon \mathrm{A}$ (3) $-\mathrm{T}(\mathrm{II})$, it has been observed that, out of the two hydrogen bond lengths, $\mathrm{N}-\mathrm{H} \cdots \mathrm{N}$ is shorter and has more linear corresponding bond angles as compared to $\mathrm{C}-\mathrm{H} \cdots \mathrm{O}=\mathrm{C}$. Similar observation is also found for the three different EA(1)-T(II), $\mathrm{EA}(2)-\mathrm{T}(\mathrm{II})$, and EA(3)-T(II) complexes. More details regarding strong or weak interaction will be discussed in next section.

(c) Energetics and Hydrogen-Bonding Energy Strength for DNA Adduct-Thymine Complexes. The total energy and the BSSE corrected hydrogen-bonding energies for the WatsonCrick $\mathrm{A}-\mathrm{T}$ base pair and different adenine adduct-thymine complexes, $[\epsilon \mathrm{A}(1)-\mathrm{T}(\mathrm{I}), \epsilon \mathrm{A}(2)-\mathrm{T}(\mathrm{I}), \epsilon \mathrm{A}(3)-\mathrm{T}(\mathrm{I})$ and $\mathrm{EA}(1)-$ $\mathrm{T}(\mathrm{I}), \mathrm{EA}(2)-\mathrm{T}(\mathrm{I}), \mathrm{EA}(3)-\mathrm{T}(\mathrm{I})]$ and $[\epsilon \mathrm{A}(1)-\mathrm{T}(\mathrm{II}), \epsilon \mathrm{A}(2)-\mathrm{T}(\mathrm{II})$, $\epsilon \mathrm{A}(3)-\mathrm{T}(\mathrm{II})$ and $\mathrm{EA}(1)-\mathrm{T}(\mathrm{II}), \mathrm{EA}(2)-\mathrm{T}(\mathrm{II}), \mathrm{EA}(3)-\mathrm{T}(\mathrm{II})]$, using B3LYP/6-31+ $\mathrm{G}^{*}$ are presented in Table 2. Out of the three different etheno-adduct-thymine(I) complexes, $\epsilon \mathrm{A}(2)-\mathrm{T}(\mathrm{I})$ complex is observed to be the most stable, whereas $\epsilon \mathrm{A}(3)-$ T(II) complex is found to be the most stable out of the three different etheno-adduct-thymine(II) complexes. The stability 
TABLE 2: Total Energy and Hydrogen-Bonding Strength for the A-T Base Pair and Different Adenine Adduct-Thymine Complexes

\begin{tabular}{llrr}
\hline & total energy $^{a}$ & \multicolumn{1}{c}{$\mathrm{BE}_{\mathrm{CP}}{ }^{b}$} & \multicolumn{1}{c}{$\mathrm{BE}_{\mathrm{CP}}{ }^{c}$} \\
\hline$\epsilon \mathrm{A}(1)-\mathrm{T}(\mathrm{I})$ & -997.69724 & -6.50 & -8.16 \\
$\epsilon \mathrm{A}(2)-\mathrm{T}(\mathrm{I})$ & -997.70773 & -13.18 & -14.54 \\
$\epsilon \mathrm{A}(3)-\mathrm{T}(\mathrm{I})$ & -997.69866 & -7.41 & -8.86 \\
$\epsilon \mathrm{A}(1)-\mathrm{T}(\mathrm{II})$ & -997.70635 & -12.26 & -13.64 \\
$\epsilon \mathrm{A}(2)-\mathrm{T}(\mathrm{II})$ & -997.69928 & -7.72 & -8.81 \\
$\epsilon \mathrm{A}(3)-\mathrm{T}(\mathrm{II})$ & -997.70749 & -13.02 & -14.22 \\
$\mathrm{EA}(1)-\mathrm{T}(\mathrm{I})$ & -998.89751 & -7.18 & -9.26 \\
$\mathrm{EA}(2)-\mathrm{T}(\mathrm{I})$ & -998.90780 & -13.81 & -15.30 \\
$\mathrm{EA}(3)-\mathrm{T}(\mathrm{I})$ & -998.89778 & -7.34 & -8.95 \\
$\mathrm{EA}(1)-\mathrm{T}(\mathrm{II})$ & -998.90751 & -13.45 & -14.98 \\
$\mathrm{EA}(2)-\mathrm{T}(\mathrm{II})$ & -998.90056 & -9.10 & -10.20 \\
$\mathrm{EA}(3)-\mathrm{T}(\mathrm{II})$ & -998.90744 & -13.47 & -14.68 \\
$\mathrm{~A}-\mathrm{T}$ & -921.51809 & -12.82 & -13.62
\end{tabular}

${ }^{a}$ Total energy (au) at B3LYP/6-31+G*. ${ }^{b}$ BSSE corrected binding energy $(\mathrm{kcal} / \mathrm{mol})$ at $\mathrm{B} 3 \mathrm{LYP} / 6-31+\mathrm{G}^{*} \cdot{ }^{c} \mathrm{BSSE}$ corrected binding energy $(\mathrm{kcal} / \mathrm{mol})$ at $\mathrm{MP} 2 / 6-311++\mathrm{G}^{* *} / / \mathrm{B} 3 \mathrm{LYP} / 6-31+\mathrm{G}^{*}$.

order is $\epsilon \mathrm{A}(2)-\mathrm{T}$ (I) complex $>\epsilon \mathrm{A}(3)-\mathrm{T}(\mathrm{II})$ complex, taking all six different etheno-adduct-thymine complexes into account. The BSSE corrected hydrogen-bonding strength is also found to be in the same sequence, $\epsilon \mathrm{A}(2)-\mathrm{T}(\mathrm{I})$ complex $(13.18 \mathrm{kcal} /$ $\mathrm{mol})>\epsilon \mathrm{A}(3)-\mathrm{T}(\mathrm{II})$ complex $(13.02 \mathrm{kcal} / \mathrm{mol})$. The hydrogenbonding strength for the most stable $\epsilon \mathrm{A}(2)-\mathrm{T}(\mathrm{I})$ complex $(13.18$ $\mathrm{kcal} / \mathrm{mol}$ ) is around $0.36 \mathrm{kcal} / \mathrm{mol}$ more as compared to Watson-Crick A-T base pair. The calculated BSSE corrected hydrogen-bonding strength for Watson-Crick A-T base pair, using B3LYP/6-31+ $\mathrm{G}^{*}$, is $12.82 \mathrm{kcal} / \mathrm{mol}$ as compared to those reported earlier, [BP86/DZVP $(13.9 \mathrm{kcal} / \mathrm{mol})^{41}$ and B3LYP/ $\left.6-31 \mathrm{G}^{* *}(12.3 \mathrm{kcal} / \mathrm{mol})\right]{ }^{42}$ From the previous section, as it has already been observed, strong interaction for $\epsilon \mathrm{A}(2)-\mathrm{T}(\mathrm{I})$ complex associated with the $\mathrm{N}-\mathrm{H} \cdots \mathrm{N}$ and $\mathrm{N}-\mathrm{H} \cdots \mathrm{O}$ hydrogen bond lengths is now confirmed to be most stable and to have the maximum amount of hydrogen-bonding strength among the different etheno-adduct-thymine complexes. Among the three different ethano-adduct-thymine(I) complexes, it has been observed from Table 2 that EA(2)-T(I) complex is most stable, and out of the three different ethano-adduct-thymine(II) complexes, the total energies for both $\mathrm{EA}(1)-\mathrm{T}$ (II) and EA(3) $-\mathrm{T}(\mathrm{II})$ are approximately same. However, EA(2)-T(I) complex is observed to be the most stable as compared to those of EA(1)-T(II) and EA(3)-T(II) complexes. The stability order is found to be $\mathrm{EA}(2)-\mathrm{T}(\mathrm{I})>\mathrm{EA}(3)-\mathrm{T}(\mathrm{II})>\mathrm{EA}(1)-\mathrm{T}(\mathrm{II})$, taking all six different ethano-adduct-thymine complexes into account. The BSSE corrected hydrogen-bonding strength is also found to be in the same sequence, $\mathrm{EA}(2)-\mathrm{T}(\mathrm{I})(13.81 \mathrm{kcal} /$ $\mathrm{mol})>\mathrm{EA}(3)-\mathrm{T}(\mathrm{II})(13.47 \mathrm{kcal} / \mathrm{mol})>\mathrm{EA}(1)-\mathrm{T}(\mathrm{II})(13.45$ $\mathrm{kcal} / \mathrm{mol})$, as compared to those of the stability order. Since it has already been observed strong interaction for EA(2)-T(I) complex associated with the $\mathrm{N}-\mathrm{H} \cdots \mathrm{N}$ and $\mathrm{N}-\mathrm{H} \cdots \mathrm{O}$ hydrogen bond lengths is now confirmed to be the most stable and to have the maximum amount of hydrogen-bonding strength among the different ethano-adduct-thymine complexes. The hydrogenbonding strength for the most stable EA(2)-T(I) complex is around $1.0 \mathrm{kcal} / \mathrm{mol}$ more as compared to Watson-Crick A-T base pair. Now considering both etheno- and ethano-adductthymine complexes, and compared to Watson-Crick A-T base pair, the BSSE corrected hydrogen-bonding strength sequence for the most stable complexes is found to be $\mathrm{EA}(2)-\mathrm{T}(\mathrm{I})>$ $\mathrm{EA}(3)-\mathrm{T}(\mathrm{II})>\mathrm{EA}(1)-\mathrm{T}(\mathrm{II})>\epsilon \mathrm{A}(2)-\mathrm{T}(\mathrm{I})>\epsilon \mathrm{A}(3)-\mathrm{T}(\mathrm{II})>$ $\mathrm{A}-\mathrm{T}$, whereas the remaining complexes are found to be less in hydrogen-bonding strength compared to A-T base pair. However, single-point energy calculations at MP2/6-311++G**//
B3LYP/6-31+G* have also been carried out and presented in Table 2, so as to include electron correlation explicitly in order to obtain good representations of dispersion and electrostatic forces that are responsible for the binding of the species. From Table 2, it can be observed that the stability sequences at MP2/ $6-311++\mathrm{G}^{* *} / / \mathrm{B} 3 \mathrm{LYP} / 6-31+\mathrm{G}^{*}$ for the etheno-adduct - thymine and ethano-adduct-thymine complexes are found to be the same in order as those obtained by B3LYP/6-31+G*. The BSSE corrected binding energy strengths computed at MP2/6$311++\mathrm{G}^{* *} / / \mathrm{B} 3 \mathrm{LYP} / 6-31+\mathrm{G}^{*}$ are not found to be the same in order as those obtained by B3LYP/6-31+G* with an exceptional increase in its value around $1.0-1.5 \mathrm{kcal} / \mathrm{mol}$. It is also interesting to note that the BSSE corrected hydrogen-bonding strength at MP2/6-311++G**//B3LYP/6-31+G* for WatsonCrick $\mathrm{A}-\mathrm{T}$ base pair is found to be $13.62 \mathrm{kcal} / \mathrm{mol}$ as compared to a previous report (MP2/DZP//HF//6-31G* $(14.7 \mathrm{kcal} / \mathrm{mol}){ }^{40}$ The BSSE corrected hydrogen-bonding strength sequence at MP2/6-311++G**//B3LYP/6-31+G* for the most stable complexes is found to be EA(2)-T(I) $(15.30 \mathrm{kcal} / \mathrm{mol})>\mathrm{EA}(1)$ $\mathrm{T}$ (II) $(14.98 \mathrm{kcal} / \mathrm{mol})>\mathrm{EA}(3)-\mathrm{T}(\mathrm{II})(14.68 \mathrm{kcal} / \mathrm{mol})>$ $\epsilon \mathrm{A}(2)-\mathrm{T}(\mathrm{I})(14.54 \mathrm{kcal} / \mathrm{mol})>\epsilon \mathrm{A}(3)-\mathrm{T}(\mathrm{II})(14.22 \mathrm{kcal} / \mathrm{mol})$ $>\epsilon \mathrm{A}(3)-\mathrm{T}$ (II) $(13.64 \mathrm{kcal} / \mathrm{mol})>\mathrm{A}-\mathrm{T}(13.62 \mathrm{kcal} / \mathrm{mol})$.

Table 3 depicts the computed reaction enthalpy and Gibbs free energy corrected binding energy values for the ethenoadduct - thymine complexes and ethano-adduct - thymine complexes by using B3LYP/6-31+G* at $298.15 \mathrm{~K}$. Figure 5 represents the comparative plot for the computed reaction enthalpies following the equation, given by

$$
\Delta H_{\text {reacn }}=\Delta E_{\text {B.O }}+\Delta E_{\text {trans }}+\Delta E_{\text {rot. }}+\Delta E_{\text {vib }}+\Delta \mathrm{ZPE}
$$

where $\Delta E_{\mathrm{B} . \mathrm{O}}=$ electronic bonding energy, $\Delta E_{\text {trans }}, \Delta E_{\text {rot., }}$, and $\Delta E_{\mathrm{vib}}$ are changes in translational, rotational, and vibrational energy, and $\triangle \mathrm{ZPE}=$ zero point vibrational energy.

From Table 3, it can be observed that the reaction enthalpy value for $\epsilon \mathrm{A}(2)-\mathrm{T}(\mathrm{I})$ is $10.05 \mathrm{kcal} / \mathrm{mol}$, which is highest among the etheno-addcut-thymine complexes and about $1.55 \mathrm{kcal} / \mathrm{mol}$ more than those obtained for Watson-Crick $\mathrm{A}-\mathrm{T}$ base pair. The Gibbs free energy corrected binding energy sequence is found to be $\epsilon \mathrm{A}(3)-\mathrm{T}$ (II) $(1.48 \mathrm{kcal} / \mathrm{mol})>\epsilon \mathrm{A}(1)-\mathrm{T}$ (II) $(1.43$ $\mathrm{kcal} / \mathrm{mol})>\epsilon \mathrm{A}(2)-\mathrm{T}(\mathrm{I})(0.86 \mathrm{kcal} / \mathrm{mol})$, which is contradictory to the BSSE corrected binding energy sequence, $\epsilon \mathrm{A}(2)-\mathrm{T}(\mathrm{I})$ $(13.18 \mathrm{kcal} / \mathrm{mol})>\epsilon \mathrm{A}(3)-\mathrm{T}(\mathrm{II})(13.02 \mathrm{kcal} / \mathrm{mol})>\epsilon \mathrm{A}(3)-$ T(II) $(12.26 \mathrm{kcal} / \mathrm{mol})$. Similarly, the reaction enthalpy value for $\mathrm{EA}(1)-\mathrm{T}$ (II) is $10.22 \mathrm{kcal} / \mathrm{mol}$, which is highest among the ethano-addcut-thymine complexes and about $1.72 \mathrm{kcal} / \mathrm{mol}$ more than those obtained for Watson-Crick $\mathrm{A}-\mathrm{T}$ base pair. The Gibbs free energy corrected binding energy sequence is found to be $\mathrm{EA}(1)-\mathrm{T}$ (II) $(2.21 \mathrm{kcal} / \mathrm{mol})>\mathrm{EA}(3)-\mathrm{T}$ (II) $(1.54$ $\mathrm{kcal} / \mathrm{mol})>\mathrm{EA}(2)-\mathrm{T}(\mathrm{I})(0.84 \mathrm{kcal} / \mathrm{mol})$, which is contradictory to the BSSE corrected binding energy sequence, EA(2)-T(I) $(13.81 \mathrm{kcal} / \mathrm{mol})>\mathrm{EA}(1)-\mathrm{T}(\mathrm{II})(13.47 \mathrm{kcal} / \mathrm{mol})>\mathrm{EA}(3)-$ T(II) $(13.45 \mathrm{kcal} / \mathrm{mol})$.

It is known that DNA damage is an alteration of the structure of a DNA molecule that prevents the molecule from being replicated and hence from being inherited. Double strand DNA damage, if not repaired, results in the loss of genetic information, which can be harmful or lethal to an individual's gametes and offspring. ${ }^{43}$ It is believed that the results discussed above for the adenine adduct and thymine interaction at the molecular level might be intriguing as compared to normal Watson-Crick adenine - thymine base pair $(\mathrm{A}-\mathrm{T})$. Due to the interaction of adenine adduct the normal sequencing has great effect as we observed throughout our discussion with regard to the geometrical structure, energetic properties, and hydrogen-bonding 
TABLE 3: Computed Reaction Enthalpy and Gibbs Free Energy Corrected Binding Energy for DNA Adduct-Thymine Complexes Using B3LYP/6-31+G* at 298.15 K (All Values, kcal/mol)

\begin{tabular}{|c|c|c|c|c|c|c|c|}
\hline & $\Delta E_{\mathrm{B} . \mathrm{O}^{a}}$ & $\Delta E_{\text {trans }}{ }^{b}$ & $\Delta E_{\text {rot. }}{ }^{c}$ & $\Delta E_{\mathrm{vib}^{d}}$ & $\Delta \mathrm{ZPE}^{e}$ & $\Delta H_{\text {reacn }}^{f}$ & $\Delta G^{g}$ \\
\hline$\epsilon \mathrm{A}(1)+\mathrm{T}(\mathrm{I}) \rightarrow \epsilon \mathrm{A}(1)-\mathrm{T}(\mathrm{I})$ & -6.64 & -0.89 & -0.89 & 3.69 & 0.65 & -4.07 & 4.12 \\
\hline$\epsilon \mathrm{A}(2)+\mathrm{T}(\mathrm{I}) \rightarrow \epsilon \mathrm{A}(2)-\mathrm{T}(\mathrm{I})$ & -13.21 & -0.89 & -0.89 & 3.87 & 1.07 & -10.05 & -0.86 \\
\hline$\epsilon \mathrm{A}(3)+\mathrm{T}(\mathrm{I}) \rightarrow \epsilon \mathrm{A}(3)-\mathrm{T}(\mathrm{I})$ & -7.53 & -0.89 & -0.89 & 3.78 & 0.79 & -4.74 & 3.70 \\
\hline$\epsilon \mathrm{A}(1)+\mathrm{T}(\mathrm{II}) \rightarrow \epsilon \mathrm{A}(1)-\mathrm{T}(\mathrm{II})$ & -12.35 & -0.89 & -0.89 & 3.92 & 0.95 & -9.26 & -1.43 \\
\hline$\epsilon \mathrm{A}(2)+\mathrm{T}(\mathrm{II}) \rightarrow \epsilon \mathrm{A}(2)-\mathrm{T}(\mathrm{II})$ & -7.91 & -0.89 & -0.89 & 3.81 & 0.80 & -5.08 & $3.25 \epsilon$ \\
\hline$\epsilon \mathrm{A}(3)+\mathrm{T}(\mathrm{II}) \rightarrow \epsilon \mathrm{A}(3)-\mathrm{T}(\mathrm{II})$ & -13.06 & -0.89 & -0.89 & 3.98 & 1.06 & -9.80 & -1.48 \\
\hline $\mathrm{EA}(1)+\mathrm{T}(\mathrm{I}) \rightarrow \mathrm{EA}(1)-\mathrm{T}(\mathrm{I})$ & -7.22 & -0.89 & -0.89 & 3.70 & 0.73 & -5.08 & 3.91 \\
\hline $\mathrm{EA}(2)+\mathrm{T}(\mathrm{I}) \rightarrow \mathrm{EA}(2)-\mathrm{T}(\mathrm{I})$ & -13.68 & -0.89 & -0.89 & 3.86 & 1.10 & -10.50 & -0.84 \\
\hline $\mathrm{EA}(3)+\mathrm{T}(\mathrm{I}) \rightarrow \mathrm{EA}(3)-\mathrm{T}(\mathrm{I})$ & -7.40 & -0.89 & -0.89 & 3.76 & 0.78 & -4.64 & 3.95 \\
\hline $\mathrm{EA}(1)+\mathrm{T}(\mathrm{II}) \rightarrow \mathrm{EA}(1)-\mathrm{T}(\mathrm{II})$ & -13.50 & -0.89 & -0.89 & 4.01 & 1.05 & -10.22 & -2.21 \\
\hline $\mathrm{EA}(2)+\mathrm{T}(\mathrm{II}) \rightarrow \mathrm{EA}(2)-\mathrm{T}(\mathrm{II})$ & -9.14 & -0.89 & -0.89 & 3.83 & 0.86 & -6.23 & 2.28 \\
\hline $\mathrm{EA}(3)+\mathrm{T}(\mathrm{II}) \rightarrow \mathrm{EA}(3)-\mathrm{T}(\mathrm{II})$ & -13.46 & -0.89 & -0.89 & 4.00 & 1.10 & -10.13 & -1.54 \\
\hline $\mathrm{A}+\mathrm{T} \rightarrow \mathrm{A}-\mathrm{T}$ & -12.63 & -0.89 & -0.89 & 4.53 & 1.56 & -8.50 & -0.05 \\
\hline
\end{tabular}

${ }^{a} \Delta E_{\mathrm{B} . \mathrm{O}}=$ electronic binding energy. ${ }^{b} \Delta E_{\text {trans }}=$ translational energy. ${ }^{c} \Delta E_{\text {rot. }}=$ rotational energy. ${ }^{d} \Delta E_{\mathrm{vib}}=$ vibrational energy. ${ }^{e} \Delta \mathrm{ZPE}=$ change in zero point vibrational energy. ${ }^{f} \Delta H_{\text {reacn }}=$ reaction enthalpies. ${ }^{g} \Delta G=$ Gibbs free energy corrected binding energy.

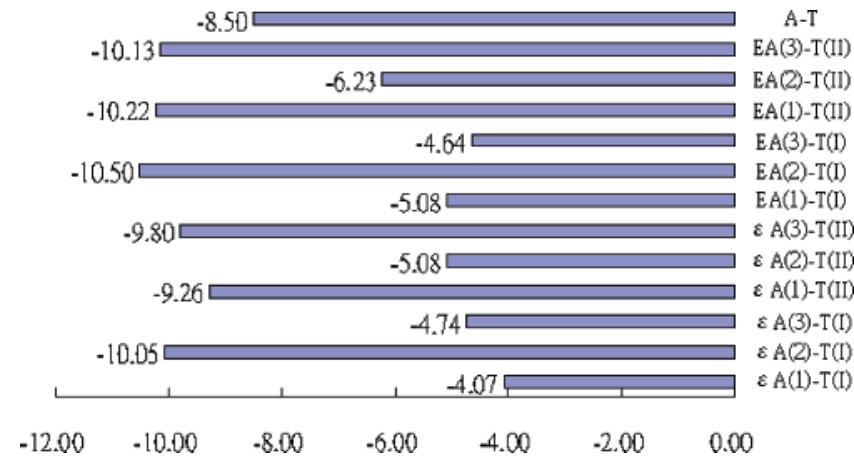

Figure 5. Comparative plot for the computed reaction enthalpy (kcal/ mol) for $\mathrm{A}-\mathrm{T}, \epsilon \mathrm{A}-\mathrm{T}$, and $\mathrm{EA}-\mathrm{T}$ complexes by using B3LYP/6$31+\mathrm{G}^{*}$ at $298.15 \mathrm{~K}$.

strengths. Such effect can be considered to provide helpful information for possible DNA damage.

\section{Conclusion}

The electronic structure calculations for DNA adductthymine complexes have been performed using density functional theory method (B3LYP/6-31+G*). DNA adducts are implicated in many types of human cancer, especially where persistent oxidative stress leads to malignancy by increasing mutations and results in the loss of genetic information, which can be harmful or lethal to an individual's gametes and offspring. The existence of DNA adducts bring the danger of carcinogenesis because of mispairing with normal DNA bases. $1, N^{6}$ ethenoadenine adducts $(\epsilon \mathrm{A})$ and $1, N^{6}$-ethanoadenine adducts (EA) have been considered as DNA adducts to study the interaction with thymine, as DNA base. To understand mispairing of DNA adducts with DNA bases, in this work, several different stable conformers for each type of adenine adduct with thymine, $[\epsilon \mathrm{A}(1)-\mathrm{T}(\mathrm{I}), \epsilon \mathrm{A}(2)-\mathrm{T}(\mathrm{I}), \epsilon \mathrm{A}(3)-\mathrm{T}(\mathrm{I})$ and $\mathrm{EA}(1)-$ $\mathrm{T}(\mathrm{I}), \mathrm{EA}(2)-\mathrm{T}(\mathrm{I}), \mathrm{EA}(3)-\mathrm{T}(\mathrm{I})]$ and $[\epsilon \mathrm{A}(1)-\mathrm{T}(\mathrm{II}), \epsilon \mathrm{A}(2)-\mathrm{T}(\mathrm{II})$, $\epsilon \mathrm{A}(3)-\mathrm{T}(\mathrm{II})$ and $\mathrm{EA}(1)-\mathrm{T}(\mathrm{II}), \mathrm{EA}(2)-\mathrm{T}(\mathrm{II}), \mathrm{EA}(3)-\mathrm{T}(\mathrm{II})]$, have been considered with regard to their interactions. The differences in its geometrical structures, energetics, and binding energies have also been compared with Watson-Crick adeninethymine base pair. The calculated hydrogen-bonding energies are corrected for the basis set superposition error (BSSE), using counterpoise method. The BSSE corrected hydrogen-bonding strength sequence for the most stable complexes is found to be $\mathrm{EA}(2)-\mathrm{T}(\mathrm{I})>\mathrm{EA}(3)-\mathrm{T}(\mathrm{II})>\mathrm{EA}(1)-\mathrm{T}(\mathrm{II})>\epsilon \mathrm{A}(2)-\mathrm{T}(\mathrm{I})>$ $\epsilon \mathrm{A}(3)-\mathrm{T}(\mathrm{II})>\mathrm{A}-\mathrm{T}$, where as the remaining complexes are found to be less in hydrogen-bonding strength compared to A-T base pair. However, single-point energy calculations at MP2/ $6-311++\mathrm{G}^{* *} / / \mathrm{B} 3 \mathrm{LYP} / 6-31+\mathrm{G}^{*}$ have been carried out, so as to include electron correlation explicitly in order to obtain good representations of dispersion and electrostatic forces that are responsible for the binding of the species and to better estimate the hydrogen-bonding strengths. The stability sequence at MP2/ $6-311++\mathrm{G}^{* *} / / \mathrm{B} 3 \mathrm{LYP} / 6-31+\mathrm{G}^{*}$ for the etheno-adduct - thymine and ethano-adduct-thymine complexes are found to be the same in order as those obtained by B3LYP/6-31+G*. The BSSE corrected hydrogen-bonding strength sequence at MP2/6$311++\mathrm{G}^{* * / / B} 3 \mathrm{LYP} / 6-31+\mathrm{G}^{*}$ for the most stable complexes is found to be $\mathrm{EA}(2)-\mathrm{T}(\mathrm{I})(15.30 \mathrm{kcal} / \mathrm{mol})>\mathrm{EA}(1)-\mathrm{T}(\mathrm{II})$ $(14.98 \mathrm{kcal} / \mathrm{mol})>\mathrm{EA}(3)-\mathrm{T}(\mathrm{II})(14.68 \mathrm{kcal} / \mathrm{mol})>\epsilon \mathrm{A}(2)-$ $\mathrm{T}$ (I) $(14.54 \mathrm{kcal} / \mathrm{mol})>\epsilon \mathrm{A}(3)-\mathrm{T}(\mathrm{II})(14.22 \mathrm{kcal} / \mathrm{mol})>\epsilon \mathrm{A}-$ (3)-T(II) $(13.64 \mathrm{kcal} / \mathrm{mol})>\mathrm{A}-\mathrm{T}(13.62 \mathrm{kcal} / \mathrm{mol})$. The calculated reaction enthalpy value for $\epsilon \mathrm{A}(2)-\mathrm{T}(\mathrm{I})$ is $10.05 \mathrm{kcal} /$ mol, which is highest among the etheno-adduct-thymine complexes and about $1.55 \mathrm{kcal} / \mathrm{mol}$ more than those obtained for Watson-Crick $\mathrm{A}-\mathrm{T}$ base pair, and similarly, the reaction enthalpy value for $\mathrm{EA}(1)-\mathrm{T}$ (II) is $10.22 \mathrm{kcal} / \mathrm{mol}$, which is highest among the ethano-adduct - thymine complexes and about $1.72 \mathrm{kcal} / \mathrm{mol}$ more than those obtained for Watson-Crick A-T base pair.

Acknowledgment. This research is supported by the National Science Council (NSC) of Taiwan, and the computational resource is partially supported by the National Center for HighPerformance Computing (NCHC), Hsin-Chu, Taiwan.

Supporting Information Available: Figure showing a normal adenine-thymine base pair and tables showing optimized parameters and comparative structural parameters. This material is available free of charge via the Internet at http:// pubs.acs.org.

\section{References and Notes}

(1) Bartsch, H. IARC. Sci. Publ. 1999, 150, 1.

(2) Bartsch, H.; Nair, J. Cancer Detect. Prev. 2004, 28, 385.

(3) Leithauser, M. T.; Liem, A; Stewart, B. C.; Miller, E. C.; Miller, J. A. Carcinogenesis 1990, 3, 463.

(4) Nair, J.; Barbin, A.; Guichard, Y.; Bartsch, H. Carcinogenesis 1995, 3,613 .

(5) Ghissassi, F. E.; Barbin, A.; Nair, J.; Bartsch, H. Chem. Res. Toxicol. 1995, 8,278

(6) Singer, B.; Bartsch, H. IARC Sci. Publ. 1999, 150

(7) Basu, A. K.; Wood, M. L.; Niedernhofer, L. J.; Ramos, L. A.; Essigmann, J. M. Biochemistry 1993, 32, 12793. 3778 . 
(9) Pandya, G. A.; Moriya, M. Biochemistry 1996, 35, 11487.

(10) Kouchakdjian, M.; Eisenberg, M.; Yarema, K.; Basu, A.; Essigmann, J.; Patel, D. J. Biochemistry 1991, 30, 1820.

(11) Guerra, F. C.; Bickelhaupt, F. M.; Snijders, J. G.; Baerends, E. J. J. Am. Chem. Soc. 2000, 122, 4117.

(12) Hobza, P.; Sponer, J. Chem. Rev. 1999, 99, 3247.

(13) Clary, D. C.; Benoit, D. M.; van Mourik, T. Acc. Chem. Res. 2000, 33,441 .

(14) Russo, N.; Toscano, M.; Grand, A. J. Phys. Chem. B 2001, 105, 4735 .

(15) Russo, N.; Toscano, M.; Grand, A. J. Am. Chem. Soc. 2001, 23, 10272

(16) Hanus, M.; Ryjacek, F.; Kabelac, M.; Kubar, T.; Bogdan, T. V.; Trygubenko, S. A.; Hobza, P. J. Am. Chem. Soc. 2003, 125, 7678.

(17) Sahu, P. K.; Mishra, R. K.; Lee, S.-L. J. Phys. Chem. A 2005, 109, 2887.

(18) Kabelac, M.; Hobza, P. J. Phys. Chem. B 2006, 110, 14515.

(19) Becke, A. D. Phys. Rev. 1988, A38, 3098.

(20) Becke, A. D. J. Chem. Phys. 1993, 98, 5648.

(21) Becke, A. D. J. Chem. Phys. 1997, 107, 8554.

(22) Schmider, H. L.; Becke, A. D. J. Chem. Phys. 1998, 108, 9624.

(23) Sim, A.; Amant, A.; Papai, I.; Salahub, D. R. J. Am. Chem. Soc.1992, 114, 4391.

(24) Kim, K.; Jordan, K. D. J. Phys. Chem. 1994, 98, 10089.

(25) Novoa, J. J.; Sosa, C. J. Phys. Chem. 1995, 99, 15837.

(26) Lundell, J.; Latajka, Z. J. Phys. Chem. A 1997, 101, 5004.

(27) McAllister, M. A. J. Mol. Struct. (THEOCHEM) 1998, 427, 39

(28) Rablen, P. R.; Lockman, J. W.; Jorgensen, W. L. J. Phys. Chem. A 1998, 102, 3782 .

(29) Langley, C. H.; Allinger, N. L. J. Phys. Chem. A 2003, 107, 5208. 363.

(30) Aloisio, S.; Hintze, P. E.; Vaida, V. J. Phys. Chem. A 2003, 106,

(31) Ruckenstein, E.; Shulgin, I. L.; Tilson, J. L. J. Phys. Chem. A 2003, 107,2289 .
(32) Wetmore, S. D.; Schofield, R.; Smith, D. M.; Radom, L. J. Phys Chem. A 2001, 105, 8718 .

(33) Rabuck, A. D.; Scuseria, G. E. Theor. Chem. Acc. 2000, 104, 439

(34) Boys, S. F.; Bernardi, F. Mol. Phys. 1970, 19, 553.

(35) Frisch, M. J.; Trucks, G. W.; Schlegel, H. B.; Scuseria, G. E.; Robb, M. A.; Cheeseman, J. R.; Montgomery, J. A., Jr.; Vreven, T.; Kudin, K N.; Burant, J. C.; Millam, J. M.; Iyengar, S. S.; Tomasi, J.; Barone, V.; Mennucci, B.; Cossi, M.; Scalmani, G.; Rega, N.; Petersson, G. A.; Nakatsuji, H.; Hada, M.; Ehara, M.; Toyota, K.; Fukuda, R.; Hasegawa, J.; Ishida, M.; Nakajima, T.; Honda, Y.; Kitao, O.; Nakai, H.; Klene, M.; Li, X.; Knox, J. E.; Hratchian, H. P.; Cross, J. B.; Bakken, V.; Adamo, C. Jaramillo, J.; Gomperts, R.; Stratmann, R. E.; Yazyev, O.; Austin, A. J.; Cammi, R.; Pomelli, C.; Ochterski, J. W.; Ayala, P. Y.; Morokuma, K. Voth, G. A.; Salvador, P.; Dannenberg, J. J.; Zakrzewski, V. G.; Dapprich, S.; Daniels, A. D.; Strain, M. C.; Farkas, O.; Malick, D. K.; Rabuck, A D.; Raghavachari, K.; Foresman, J. B.; Ortiz, J. V.; Cui, Q.; Baboul, A. G.; Clifford, S.; Cioslowski, J.; Stefanov, B. B.; Liu, G.; Liashenko, A.; Piskorz, P.; Komaromi, I.; Martin, R. L.; Fox, D. J.; Keith, T.; Al-Laham, M. A.; Peng, C. Y.; Nanayakkara, A.; Challacombe, M.; Gill, P. M. W. Johnson, B.; Chen, W.; Wong, M. W.; Gonzalez, C.; Pople, J. A. Gaussian 03, Revision C.02; Gaussian, Inc.: Wallingford, CT, 2004.

(36) Seeman, N. C.; Rosenberg, J. M.; Suddath, F. L.; Kim, J. J. P. Rich, A. J. Mol. Biol. 1976, 104, 109

(37) Meyer, M.; Sühnel, J. J. Biomol. Struct. Dyn. 1997, 15, 619.

(38) Gould, I. R.; Kollman, P. A. J. Am. Chem. Soc.1994, 116, 2493. (39) Sponer, J.; Leszczynski, J.; Hobza, P. J. Phys. Chem.1996, 100, 1965.

(40) Brameld, K.; Dasgupta, S.; Goddard, W. A., III. J. Phys. Chem. B 1997, 101, 4851.

(41) Santamaria, R.; VaŸquez, A. J. Comput. Chem. 1994, 15, 981.

(42) Bertran, J.; Oliva, A.; Santiago, R. L.; Sodupe, M. J. Am. Chem. Soc. 1998, 120, 8159 . 1277. 